\title{
The use of a specific protocol for initiation of tolvaptan therapy in mild/moderate euvolemic hyponatremia secondary to SIADH: not a single case of overcorrection
}

\section{A. Amengual-Galbarte1, A. Ortolá-Buigues², I. Crespo -Hernández 1', R. Penso-Espinoza', T .Ruiz-Gracia1', E. Gómez-Hoyos², M. Cuesta-} Hernández, ${ }^{3}$ A. Santiago-Pérez ${ }^{1}$, AL. Calle-Pascuall ${ }^{1}$ I. Runkle. ${ }^{1}$

${ }^{1}$ Hospital Clínico San Carlos, Madrid, Spain. ${ }^{2}$ Hospital Clínico, Valladolid, Spain. ${ }^{3}$ Beaumont Hospital, Dublin, Ireland

\section{OBJETIVES}

The syndrome of innapropriate antidiuretic hormone secretion (SIADH) is the most common cause of hyponatremia (serum sodium $<135 \mathrm{mmol} / \mathrm{L}$ ) in clinical practice.

The use of oral Tolvaptan (TV) for treatment of this condition has been shown to be safe and effective in well-designed, randomized clinical trials ${ }^{1,2}$.The ESE guideline ${ }^{3}$ states a risk for overcorrection of serum sodium levels $(\mathrm{SNa})$ with vaptans, thus increasing the possibility of developing the Osmotic Demyelination Syndrome (ODS). The recommended initial dose of Tolvaptan is $15 \mathrm{mg}$, although some physicians use $7.5 \mathrm{mg}$ the first day to reduce the potential risk of serum sodium overcorrection. We had previously reported our preliminary data in 7 patients ${ }^{4}$, indicating that an initial dose of $7.5 \mathrm{mg}$ of Tolvaptan was safe and effective in SIADH in this small group of patients. Our current protocol does not only include an inital dose of 7.5 $\mathrm{mg}$, but also measures to brake the Serum Sodium rise on day 1 when necessary. Our aim was to evaluate the effectiveness and safety of our protocol.

\section{METHODS}

This single centre, retrospective study included 86 patients with mild or moderate hyponatremia due to SIADH, treated between 2011 and 2015 in the Hospital Clínico San Carlos Hospital in Madrid, Spain. TV was either administered during conventional hospitalization or under supervision in our Endocrine Day Hospital. The protocol includes baseline assessment, as well as 6,24 and 48 hours following the initial $7.5 \mathrm{mg}$ dose of TV: Serum glucose, creatinine, urea, sodium corrected for total proteins and glycemia, plasma osmolarity, urine sodium and osmolarity were determined. Overcorrection was defined as a $\mathrm{SNa}$ rise over $10 \mathrm{mmol} / \mathrm{L}$ in 24 hours or over $18 \mathrm{mmol} / \mathrm{L}$ in 48 hours. In patients at risk for development of ODS (malnutricion, hipocalemia, alcoholism, liver disease), overcorrection was defined as a SNa rise over $8 \mathrm{mmol} / \mathrm{L}$ in any 24-hour period, during the first 48 hours following initiation of therapy. Statistic analysis was performed using SPSS software statistics 21 , with Student's T test, $X^{2}$, and Spearman's Rho. Na in mmol/L. Osm in mOsm/Kg

DEPICTION OF OUR SPECIFIC PROTOCOL FOR INITIATION OF TOLVAPTAN IN MILD OR MODERATE HYPONATREMIA DUE TO SIADH

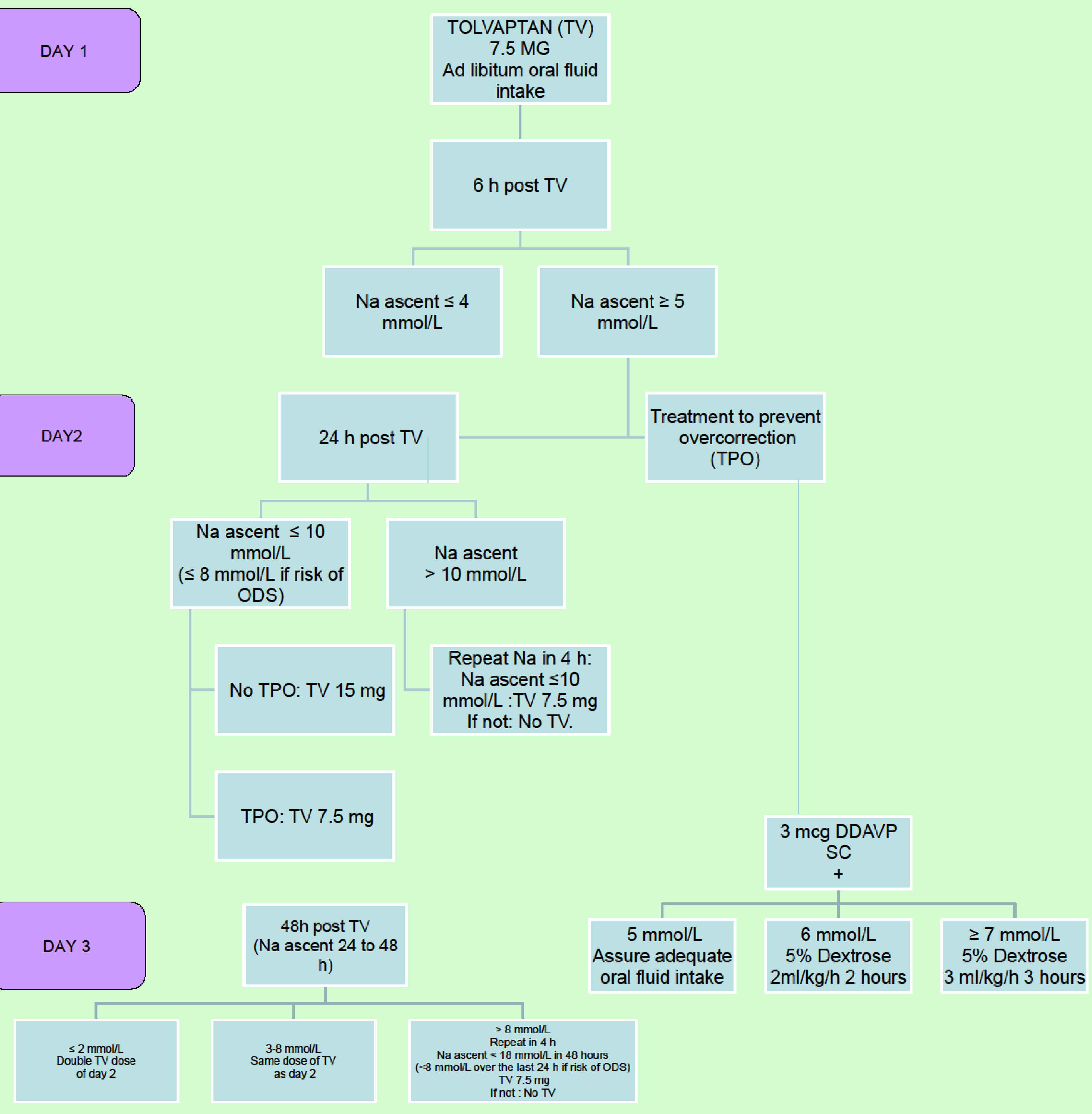

\section{RESULTS}
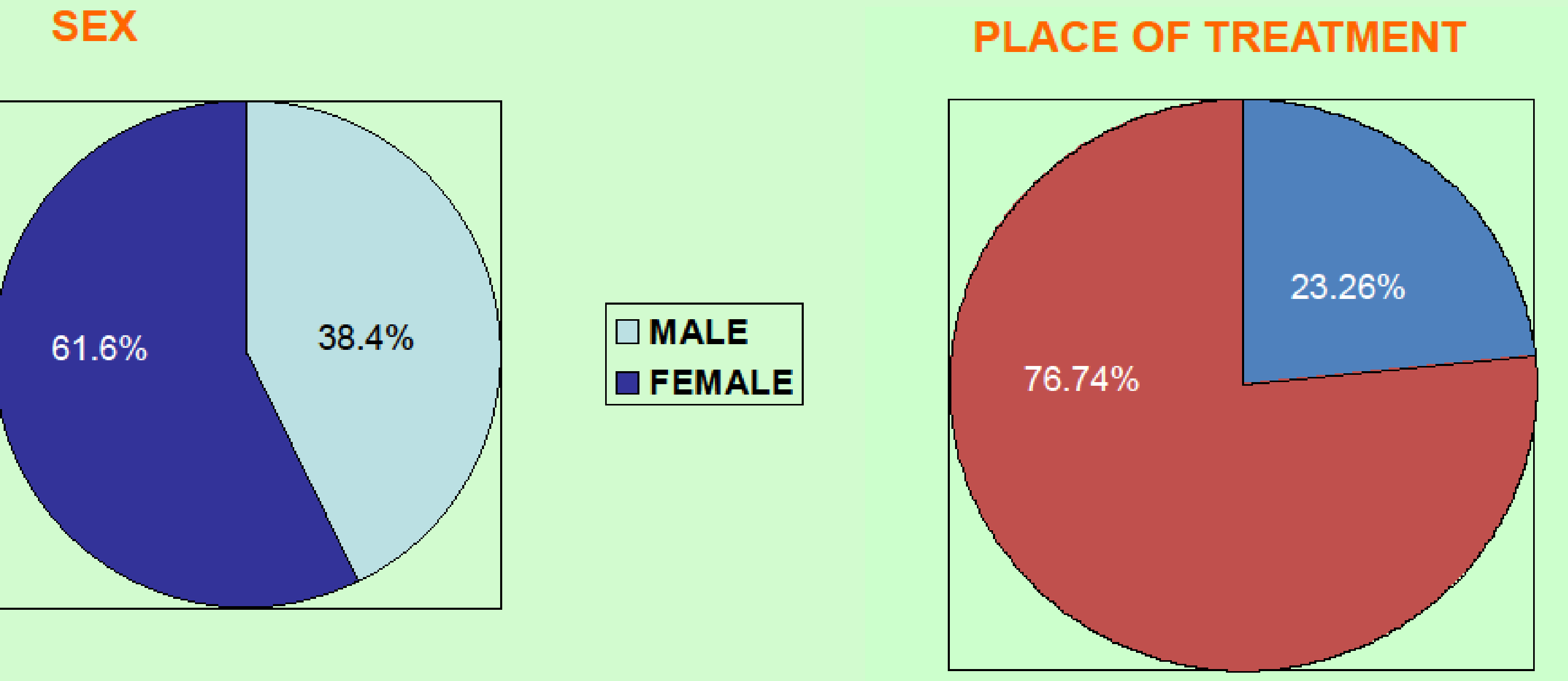

DAY HOSPITAL

CONVENTIONAL HOSPITALIZATION

ETIOLOGY
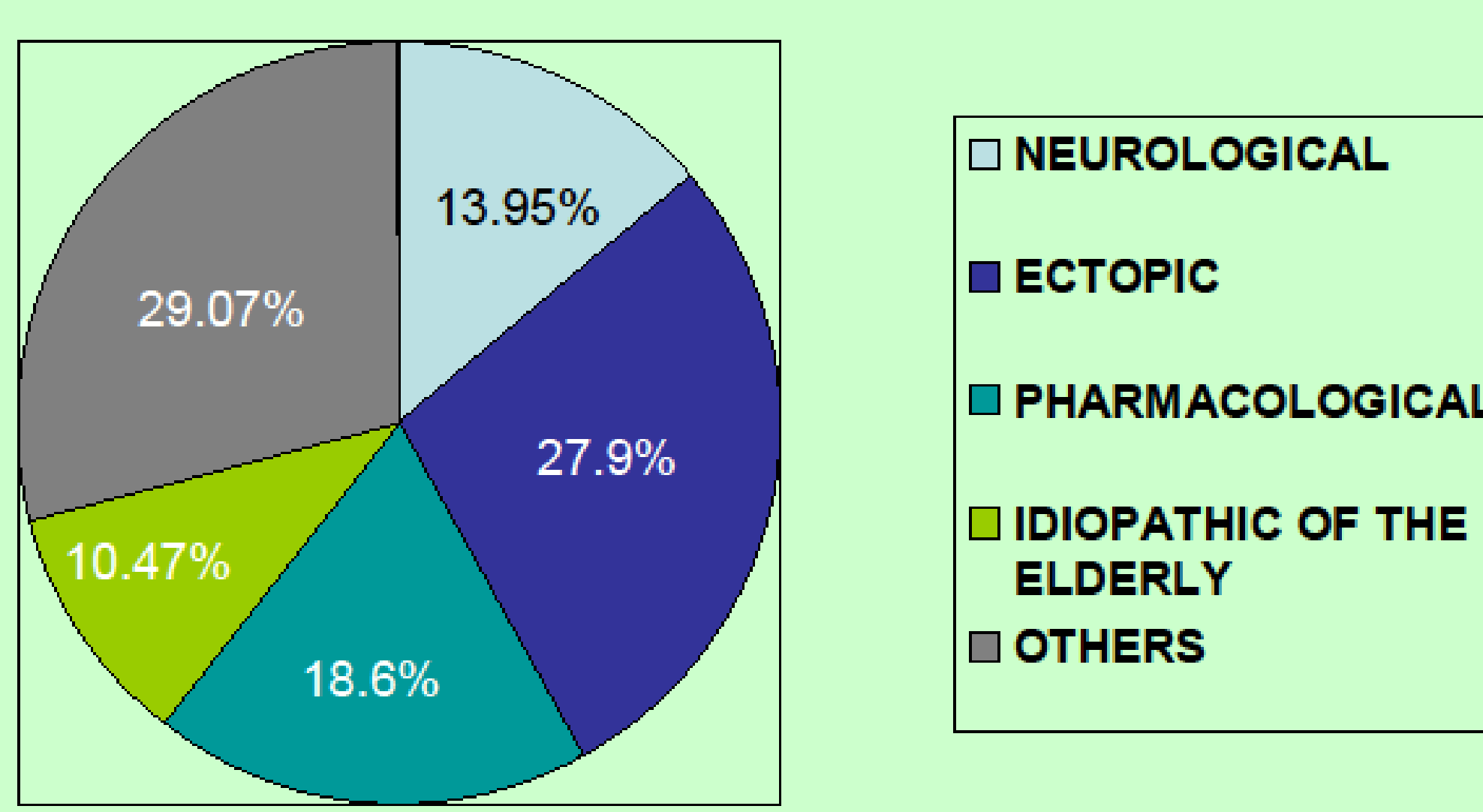

BASALINE CHARACTERISTICS

\begin{tabular}{|l|l|}
\hline Serum Sodium & $128.24(\mathrm{SD} 4.14) \mathrm{mmol} / \mathrm{L}$ \\
\hline Plasma osmolarity & $266.43(\mathrm{SD} 9.16) \mathrm{mOsm} / \mathrm{Kg}$ \\
\hline Urine osmolarity & $450.1(\mathrm{SD} 153.32) \mathrm{mOsm} / \mathrm{Kg}$ \\
\hline Spot Urine sodium & $85.18(\mathrm{SD} 44.28) \mathrm{mmol} / \mathrm{L}$ \\
\hline Serum Uric Acid Concentration & $3.07(\mathrm{SD} 1.43) \mathrm{mg} / \mathrm{dl}$ \\
\hline Creatinine & $0.67(\mathrm{SD} 0.23) \mathrm{mg} / \mathrm{dl}$ \\
\hline Furst formula & $0.92(\mathrm{SD} 0.36)$ \\
\hline
\end{tabular}

42/86 (48\%) patients had 48-hour a serum sodium above $135 \mathrm{mmol} / \mathrm{L}$.

Serum Na rise $\geq 5 \mathrm{mmol} / \mathrm{L}, 6$ hours postTV occurred in $13 / 86(15.1 \%)$ and it was significantly associated with:

- Therapy in the Endocrine Day Hospital $\mathrm{p}=0.001$

- Lower basal serum sodium

$\mathrm{R}=-0.292, \mathrm{p}=0.006$

- Lower basal uric acid concentration $R=-0.382 p=0.005$

Not a single patient presented overcorrection of SNa levels $24 \mathrm{~h}$ or 48 hours following initiation of therapy.

- The maximum 24-hour serum sodium rise over the first 24 hours following the initial dose was $10 \mathrm{mmol} / \mathrm{L}$ in two patients; whereas one patient corrected $15 \mathrm{mmol} / \mathrm{L}$ in the first 48 hours.

$10 \%$ of patients did not respond to the initial $7,5 \mathrm{mg}$ dose of TV, yet did respond to the 15 $\mathrm{mg}$ dose.

Side effects

Two patients referred intense thirst. No patient developed ODS.
SERUM Na RISE AND PLACE OF TREATMENT

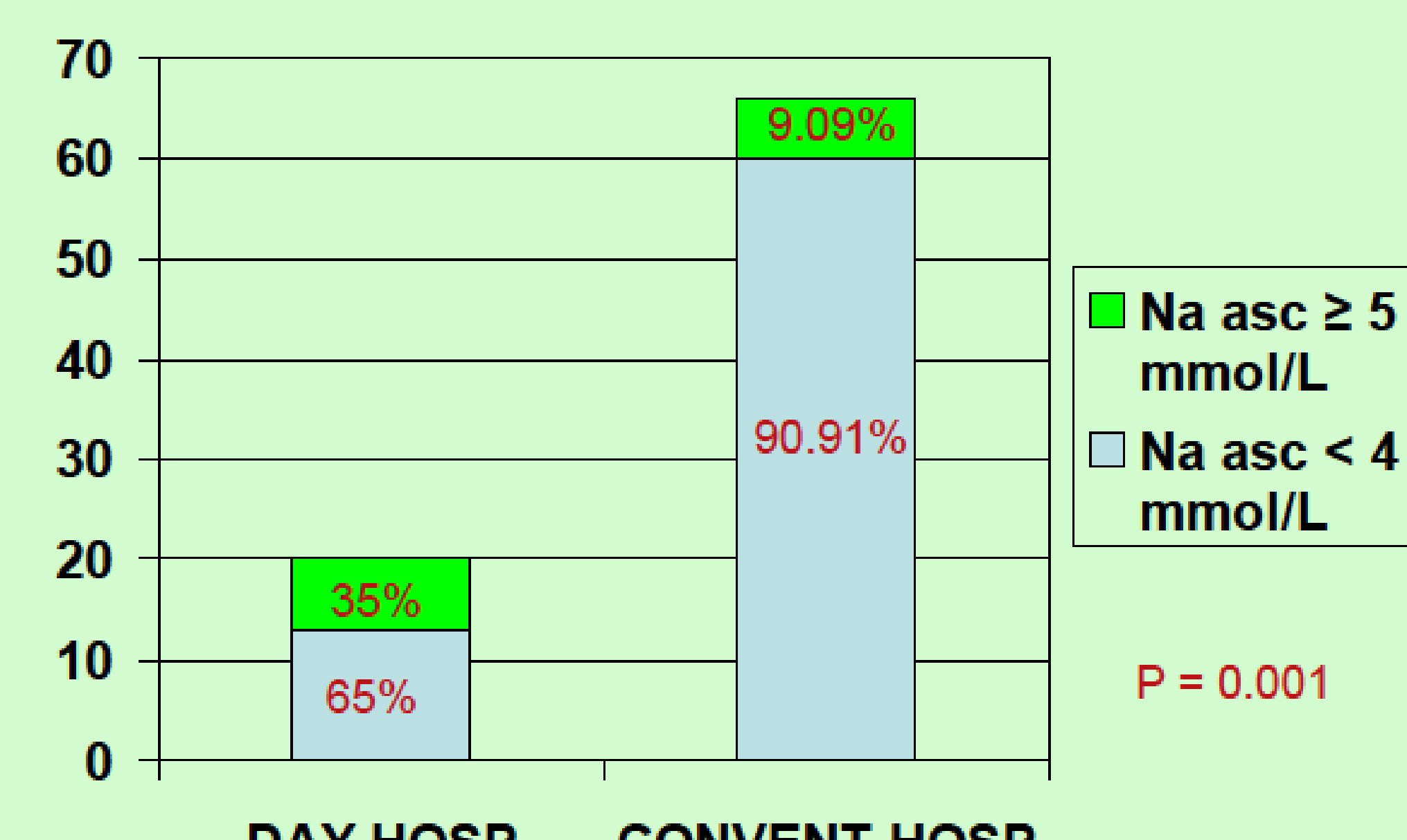

DAY HOSP CONVENT HOSP

MEAN RISE IN SNa IN ALL PATIENTS AND IN PATIENTS WITH 6-HOUR SNa RISE $\geq 5$ MMOLIL.

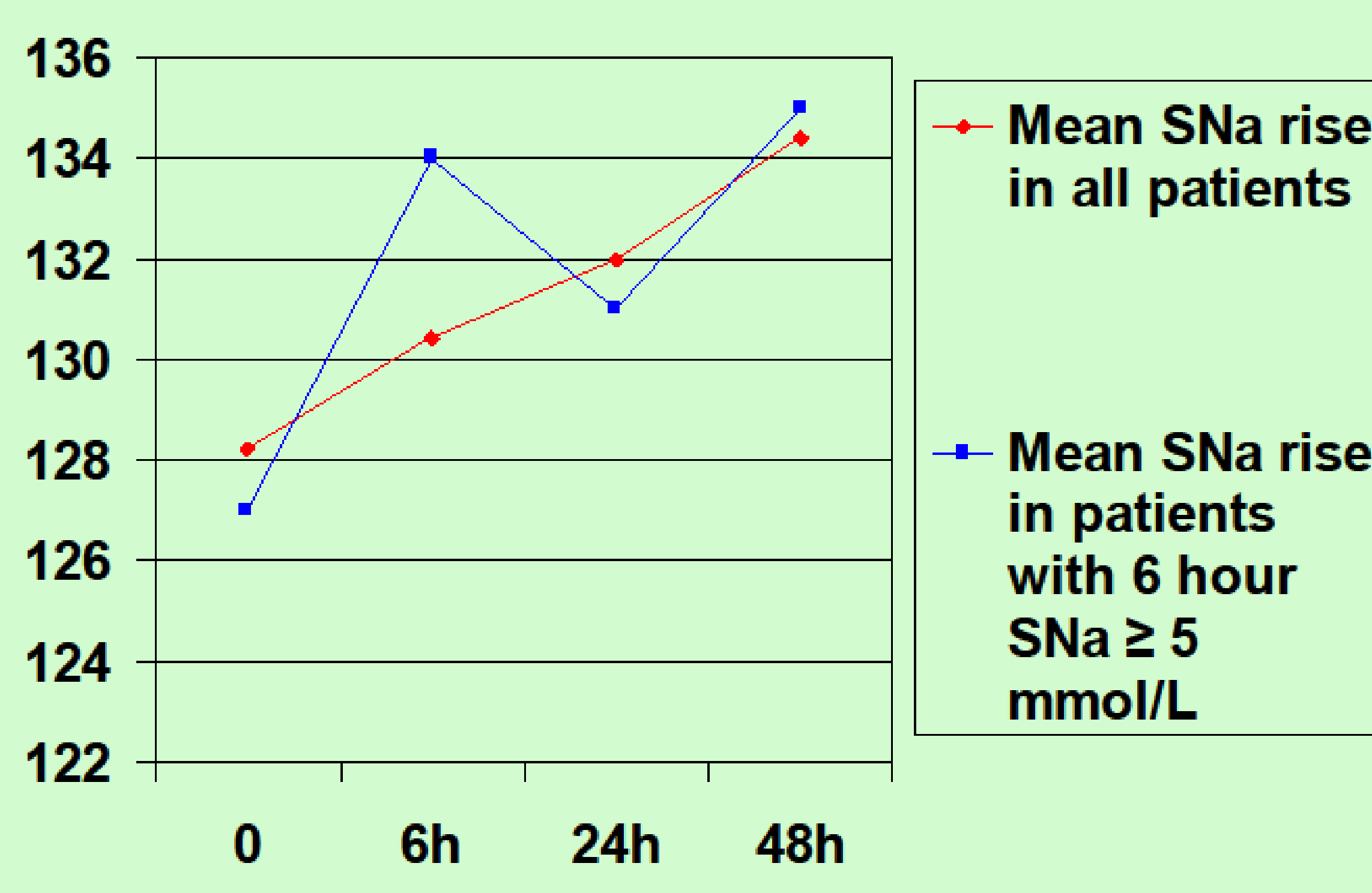

\section{CONCLUSION}

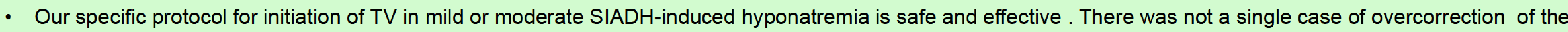
serum sodium in our patients. No patient developed ODS

- Almost half of the patients presented a normal serum sodium concentration 48 hours after initiation of TV therapy

- We must improve patients' fluid intake at our Endocrine Day Hospital.

\section{REFERENCES:}

Schrier RW et al. Tolvaptan, a selective oral vasopressin V2-receptor antagonist, for hyponatremia. N Engl Med. 2006 Nov 16;355(20):2099-112 